\title{
Epidemiological survey of Lutzomyia longipalpis infected by Leishmania infantum in an endemic area of Brazil
}

\author{
Levantamento epidemiológico de Lutzomyia longipalpis infectada por \\ Leishmania infantum em área endêmica do Brasil
}

Ana Caroline Moura Rodrigues ${ }^{1}$; Rafaella Albuquerque Silva ${ }^{1}$; Luciana Magalhães Melo $^{2}$; Maria Claudia Santos Luciano ${ }^{2}$; Claudia Maria Leal Bevilaqua ${ }^{1 *}$

\author{
${ }^{1}$ Laboratório de Doenças Parasitárias, Faculdade de Veterinária, Universidade Estadual do Ceará - UECE, Fortaleza, CE, Brasil \\ ${ }^{2}$ Laboratório de Fisiologia e Controle da Reprodução, Faculdade de Veterinária, Universidade Estadual do Ceará - UECE, \\ Fortaleza, CE, Brasil
}

Received August 27, 2013

Accepted January 30, 2014

\begin{abstract}
The objective of this study was to perform an epidemiological survey to determine the areas at risk of visceral leishmaniasis through the detection and quantification of natural infection by Leishmania infantum in Lutzomyia longipalpis. The sandflies were captured between February 2009 and January 2010, at 21 sites in four regions of the Fortaleza municipality. Samples were screened for the presence of Leishmania DNA by Real Time PCR (qPCR), amplification of kDNA minicircle sequence. Out of the 123 pools of analyzed sandflies, 45 were positive for $L$.infantum, and the minimum infection rate was $3.7 \%$. In the north, south, east and west regions, the pool screen assay predicted sand-fly infection prevalence of $3.4 \%, 4.7 \%, 4.9 \%$ and $8.4 \%$, respectively. The parasite load ranged from $2.45 \pm 0.96$ to $2,820,246 \pm 106,072$. No statistical differences were found with respect to the frequency of sand-fly infection between the regions $(\mathrm{P}=0.3014)$, seasons $(\mathrm{P}=0.3906)$ or trap locations $(\mathrm{P}=0.8486)$. Statistical differences were found with respect to the frequency of sand-fly infection between the two seasons only in the west region ( $\mathrm{P}=0.0152)$. The $\mathrm{qPCR}$ was able to detect and quantify $L$. infantum in L. longipalpis, therefore succeeding in identifying the areas of greatest risk of VL transmission.
\end{abstract}

Keywords: Leishmania infantum, Lutzomyia longipalpis, minimum infection rate, qPCR.

\section{Resumo}

O objetivo foi realizar um estudo epidemiológico para determinar as áreas de risco de transmissão de leishmaniose visceral pela detecção e quantificação de infecçôes naturais por Leishmania infantum em Lutzomyia longipalpis. As coletas foram realizadas entre fevereiro de 2009 e janeiro de 2010 em 21 locais, distribuídos em quatro regióes do município de Fortaleza. As amostras foram testadas quanto à presença de DNA de Leishmania por PCR em tempo real (qPCR). Dos 123 pools de flebotomíneos investigados, 45 foram positivos para L. infantum, e a taxa de infecção mínima foi de 3,7\%. Nas regióes Norte, Sul, Leste e Oeste, a prevalência de flebotomíneos infectados foi de 3,4\%, 4,7\%, 4,9\% e $8,4 \%$, respectivamente. A carga de parasitas nos pools variou de $2,45 \pm 0,96$ a $2.820 .246 \pm 106.072$. Náo foram observadas diferenças significativas na frequência de flebotomíneos infectados entre as regióes $(P=0,3014)$, estação do ano $(P=0,3906)$ ou localização da armadilha $(P=0,8486)$. Foram observadas diferenças significativas na frequência de flebotomíneos somente na região oeste durante a estação chuvosa $(\mathrm{P}=0,0152)$. A qPCR foi capaz de detectar e quantificar $L$. infantum em L. longipalpis, identificando as áreas de maior risco de transmissão de leishmaniose visceral.

Palavras-chave: Leishmania infantum, Lutzomyia longipalpis, taxa de infecçāo mínima, qPCR.

\footnotetext{
*Corresponding author: Claudia Maria Leal Bevilaqua

Laboratório de Doenças Parasitárias, Faculdade de Veterinária, Universidade

Estadual do Ceará - UECE, Av. Dedé Brasil, 1700,

CEP 60714-903, Fortaleza, CE, Brazil

e-mail: bevilaqua.uece@gmail.com
} 


\section{Introduction}

Visceral leishmaniasis (VL) constitutes a public health problem that affects millions of people throughout the world (DESJEUX, 2004). In South America and Europe, the causative agent of VL is Leishmania (Leishmania) infantum, a protozoan parasite transmitted by sandflies of the genus Lutzomyia in the New World and the genus Phlebotomus in the Old World, which are both widely distributed in both wild and domestic surroundings (KILLICK-KENDRICK, 1999). In South America the domestic dog is the main reservoir in urban areas, and the sylvatic hosts are foxes (Lycalopex vetulus and Cerdocyon thous), opossums (Didelphis spp.) and rodents (Rattus rattus), but confirmation of these hosts as primary or secondary reservoirs requires further xenodiagnosis studies at the population level (QUINNELL; COURTENAY, 2009).

Determining the rate of infection of sandflies by Leishmania spp. is an important tool for epidemiological studies of leishmaniasis and vector competence (SOARES et al., 2010). The classic method used to identify the parasite in the sandflies' gut is the dissection of the digestive tract, followed by direct microscopic examination. However, a limitation of this technique is the difficulty associated with the processing of a large number of specimens (PEREZ et al., 2007). The advantage of dissection should also be mentioned, i.e., the detection of developmental infectious stages with recording of metacyclic forms in the foregut (SADLOVA et al., 2011).

Recent studies of natural infection and parasite-host interaction have used real-time PCR (qPCR), a technique capable of quantifying the parasite load (GOMÉZ-SALADÍN et al., 2005; RANASINGHE et al., 2008; BEZERRA-VASCONCELOS et al., 2011). Although the molecular methods have the disadvantage of not being able to detect the parasite's viability, since DNA detection cannot be distinguished between flourishing and abortive gut infections with dead organisms (CUVILLIER et al., 2003).

Insect-vector disease prevention is very difficult in practice, especially when associated with the existence of domestic and wild reservoirs and environmental aspects (GONTIJO; MELO, 2004). The quantification of Leishmania spp in sandflies may be important in the analysis of the epidemiological differences observed between foci of VL and a view to the application of vector control measures (MONTOYA-LERMA et al., 2003). Thus, the objective of this study was to perform an epidemiological survey to determine the areas at risk for $\mathrm{VL}$ through the detection and quantification of Leishmania infantum in Lutzomyia longipalpis in an endemic area in Northeastern Brazil.

\section{Materials and Methods}

\section{Study area}

The city of Fortaleza $\left(03^{\circ} 43^{\prime} 01^{\prime \prime} \mathrm{S}, 38^{\circ} 32^{\prime} 34^{\prime \prime} \mathrm{W}\right)$ is located on the Atlantic coast and occupies an area of $315 \mathrm{~km}^{2}$ in the southern part of the state of Ceará. The estimated population in 2010 was $2,452,185$ inhabitants, with a population density of approximately 7786.52 persons per $\mathrm{km}^{2}$ (IBGE, 2011). The climate is tropical and hot, with an average annual temperature of $26^{\circ} \mathrm{C}$. The average rainfall is $1,600 \mathrm{~mm}$, and the heaviest rains are concentrated between February and May. The months of December and January are the warmest, and July the coldest. The vegetation is typical of the coastal area, with mangrove forests and "restinga". The vegetation in the city is diverse, but includes many fruit trees (IBGE, 2011).

\section{Method of capture and trap locations}

The capture sites were chosen to cover 21 neighborhoods, in the four urban regions (north, south, east and west) of the city of Fortaleza (Figure 1). One trap was placed inside, another outside each dwelling and, where possible, anotherone close to a neighboring domestic animal shelter. All sampling sites showed abundant vegetation, mainly fruit trees. Regarding the presence of domestic animals, dogs and birds were found at most collection points, particularly in the south. The selection of neighborhoods was based on the occurrence of human cases of visceral leishmaniasis reported in the years from 2005 to 2009 . The captures were carried out from $6 \mathrm{pm}$ to $6 \mathrm{am}$ for four consecutive nights each month, from February 2009 to January 2010, using CDC-type light traps (SUDIA; CHAMBERLAIN, 1962).

\section{Identification and organization of phlebotomine samples}

After the captures, the sandflies were killed with cottonwool balls soaked with ethyl acetate. The identifications were based only on external morphology, i.e. wings, head and flagellomere (YOUNG; DUNCAN, 1994). The specimens were analyzed by qPCR, using the entire insect (PAIVA et al., 2007). The L. longipalpis females, both unfed and blood-fed, were grouped in 10 specimen pools based on the capture region (north, south, east and west), trap location (indoors or outdoors) and season of year (dry or wet). Samples of the dry season were collected from February to June 2009 and in January 2010, but the sandflies of the wet season were captured between the months of July and December 2010. Three samples of 30 male sandflies were used to create the standard curve for $L$. longipalpis gene amplifications. All samples were preserved in tubes containing isopropanol and stored at $-20^{\circ} \mathrm{C}$ until DNA extraction.

\section{Real time PCR}

The qPCR assay was performed according to the protocol suggested by Bezerra-Vasconcelos et al. (2011). The specificity of each reaction was ascertained after the completion of the amplification protocol, by performing melt curve analysis (55$95^{\circ} \mathrm{C}$, initiating fluorescence acquisition at $55^{\circ} \mathrm{C}$ and taking measurements at 10-second intervals until the temperature reached $95^{\circ} \mathrm{C}$ ). There were two negative controls with male sandflies and without DNA templates.

\section{Leishmania strains}

Two Leishmania strains were used to establish standard curves for kDNA amplification and to access the primer specificities. The L.infantum strain (MHOM 46/LC/HZ1) was cultured according 


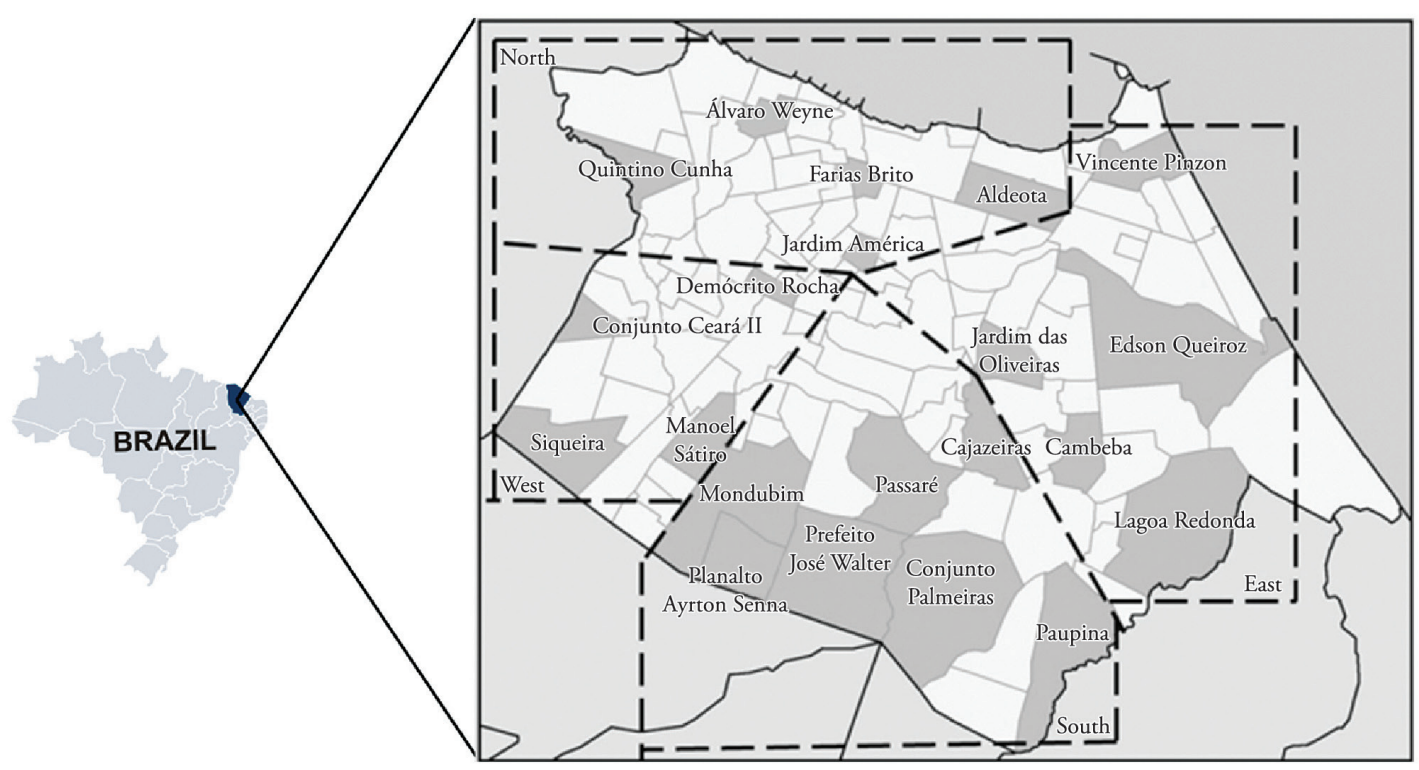

Figure 1. Location of the city of Fortaleza, Ceará State, Brazil. Dotted lines mark the regions with the neighborhoods (gray areas) from which the sandflies were collected.

to Bezerra-Vasconcelos et al. (2011). Counts were made in triplicate for a total of six counts, with a mean \pm standard deviation of $8.056 \pm 0.08 \times 10^{6}$ parasites per pellet. The L. braziliensis strain (MHOM/BR/01/BA788) was cultured according to Oliveira et al. (2004). The counts were made in triplicate for a total of six counts, with a mean \pm standard deviation of $8.004 \times 10^{6} \pm 0.008$ parasites per pellet. The remaining pellets were stored at $-20^{\circ} \mathrm{C}$ until DNA extraction.

\section{DNA extraction}

About $20 \%$ of the females collected were subjected to DNA extraction and qPCR. Additionally, the minimum number of pools was 3 per region, trap location and season. DNA was extracted using the Wizard SV Genomic DNA Purification System Kit (Promega Corporation, USA). Briefly, samples were macerated and incubated overnight at $55^{\circ} \mathrm{C}$ in a digestion solution containing $20 \mu \mathrm{l}$ proteinase $\mathrm{K}, 50 \mu \mathrm{l}$ EDTA and $5 \mu \mathrm{l}$ RNase A. After the cell debris was removed by centrifugation $(4000 \mathrm{x}$ ) $)$, the samples were transferred to spin columns and eluted in $100 \mathrm{ml}$ of water. Only the first elution was used in the qPCR.

\section{Primers}

For amplification of the Leishmania kDNA gene (a minicircle sequence for $\mathrm{kDNA}$ ) and the L. longipalpis V-ATP gene (for V-ATPase protein), we used the primers pairs described by BezerraVasconcelos et al. (2011). To identify the species Leishmania, we used the L. infantum MTHD gene (for methylenetetrahydrofolate dehydrogenase-like protein) and L. braziliensis RNase III gene (for RNase III domain), described by Peacock et al. (2007) (Table 1).

Initially all the pools were tested using the Leishmania kDNA gene. Only the positive pools with more than 10 parasites were analyzed for $L$. infantum, using the MTHD primers. The proportion of infected sandflies and parasite loads are derived from qPCRs using the kDNA primers. The quantification pools with more than 10 parasites (i.e. 100 parasites in the pool of 10 sandflies) were made in triplicate.

\section{Analysis of qPCR data}

The threshold and threshold cycle $\left(\mathrm{C}_{\mathrm{t}}\right.$ ) values were automatically determined by Realplex 2.2 software (Eppendorf), using default parameters. The specificity of the reaction was determined by the analysis of the melting curves. The $\mathrm{C}_{\mathrm{t}}$ and melting temperature $\left(\mathrm{T}_{\mathrm{m}}\right)$ were expressed as the mean \pm standard deviation of three measurements. To establish standard curves, serial dilutions of L. infantum and L. longipalpis DNA were subjected to qPCR amplification. The standard curves were also used to determine the detection limit of the assay and to assess the linearity $\left(\mathrm{R}^{2}\right)$ and the efficiency (E) of the qPCR amplifications. The efficiency was determined according to the equation $\mathrm{E}=10^{(-1 / S)}-1$, where $S$ was the slope of the standard curve generated from tenfold serial dilutions of purified parasite or sand-fly DNA. The mean $\mathrm{C}_{t}$ values for the samples were interpolated using the standard curves generated during the amplification of the Leishmania genes.

\section{Detection of parasites}

The high parasite load was considered from 10 parasites per pool (i.e. 100 parasites in the pool of 10 sandflies), and low load up to 10 parasites per pool (KIMBLIN et al., 2008; SECUNDINO et al., 2012).

\section{Calculations and statistical analysis}

The parasite load was determined by kDNA absolute quantification. Thus, the number of parasites present in 10 sandflies 
was calculated by interpolation of the average $\mathrm{Ct}$ value in the kDNA standard curve plotted with $L$. infantum strains.

Since the specimens were pooled, a minimum infection rate (MIR) for the insects was calculated as: MIR = number of positive groups $\times 100 /$ total number of insects (PAIVA et al., 2006). Samples were considered positive for parasite load starting at 1 parasite per pool. Statistical analysis was performed using SPSS V19. The Fisher exact test at a significance level of 5\% was used to compare the proportion of infected flies by the parasite among regions, seasons and trap locations. The Bonferroni test was used to verify the presence of false negatives between the regions.

The prevalence of infection in the population was then determined using the pool screen assay developed by Katholi et al. (1995). The pool screen assay provides estimates of the prevalence of infection in the vector population, based on the pool's size, the number of pools examined, and the number of negative pools (Table 2).

\section{Results}

\section{Sensitivity and specificity of the reaction}

The specificity of qPCR amplification to detect and quantify Leishmania spp. parasites in sandflies was demonstrated using only one strain of each species. The MTHD, RNase III and kDNA primers showed similar specificity in amplifying one melting peak per gene only in the presence of Leishmania DNA. L. longipalpis DNA did not interfere with $\mathrm{kDNA}, \mathrm{MTDH}$ and RNase III genes amplifications. V-ATP primer also showed similar specificity, producing one melting peak only in the presence of L. longipalpis DNA. Additionally, no amplicons were observed in the negative controls. Amplicon detection was linear over a seven log-fold range of Leishmania DNA concentrations and the assay allowed us to accurately detect as few as $0.46 \mathrm{fg}$ of parasite DNA corresponding to $0.008 \mathrm{~L}$. infantum. Amplification targeting the V-ATP gene was linear over a five log-fold range of $L$. longipalpis concentrations. The amplification efficiencies for $\mathrm{kDNA}$ and V-ATP genes were found to be high and constant with a strong correlation coefficient over the concentration/dilution range studied. The final concentrations of parasite DNA/reaction ranged from 80.560 to 0.008 , whereas the amount of sand-fly DNA/reaction ranged from 0.3 to 0.00003 .

\section{Quantification of parasite load in L. longipalpis}

The total numbers of analyzed specimens were 480, 450, 180 and 120 , originated from the north, south, east and west regions, respectively. Natural infection by $L$. infantum was detected in 45 pools, the minimum infection rate was $3.7 \%$. 14/45 positive samples showed high parasite load, between $118.9 \pm 1.4$ to 2,820,246 $\pm 106,072$ parasites per pool (Table 3). 31/45 had low parasite load, among $2.45 \pm 0.96$ to $10.57 \pm 5.98$ parasites per pool (Table 4). No sand-fly was infected with L. braziliensis.

Table 2 presents the prevalence of $L$. infantum infection in the five collection points, as determined by qPCR screening of pools. In the north, south, east and west regions, the pool screen assay predicted a prevalence of $3.4 \%, 4.7 \%, 4.9 \%$ and $8.4 \%$, respectively. Analysis of the prevalence confidence intervals demonstrated that there were no statistically difference from one another $(P>0.05)$.

Regarding distribution of $L$. longipalpis samples analyzed for L.infantum infection, no statistical differences were found with regards to sand-fly infection between the variables analyzed. Thus, the infection is not dependent on the regions $(\mathrm{P}=0.3014)$, season $(\mathrm{P}=0.3906)$ or trap location $(\mathrm{P}=0.8486)$. The Bonferroni correction verified there was no false negative among the regions.

Table 1. Oligonucleotides used to amplify Leishmania infantum, Leishmania braziliensis and Lutzomyia longipalpis genes in real-time PCR assays.

\begin{tabular}{ccccc}
\hline Gene & Organism & Accession number & \multicolumn{1}{c}{ Primer sequence (5'-3') } & Product size (bp) \\
\hline kDNA & Leishmania spp. & AF103738 & CTCCGGGTAGGGGCGTTC & 122 \\
& & & GCCCTATTTTACACCAACCCC & \\
V-ATP & L. longipalpis & EF156436 & ACGTGACGAGCAAGCAGGGG & 107 \\
& & & GCCGAGATCGTCCGACAGGC & \\
MTHD & L.infantum chagasi & XM_001465516 & ACCCCCACCACCCTGCTGTT & 76 \\
& & & GCAGCGCGAGTACCCAAGCA & \\
RNase III & L. braziliensis & XM_001565061 & GGTGGCAGCGACCACGAAGA & \\
& & & GGCCTTGGCGAGAGTGGCAG & \\
\hline
\end{tabular}

${ }^{2}$ The primers were designed from multiple alignments of L. infantum chagasi (AF103738, AF169138, AF103739, AF169137, AF169132, AF308682) minicircle sequences for $\mathrm{kDNA}$.

Table 2. Calculated prevalence of Leishmania infantum in Lutzomyia longipalpis populations by pool screen.

\begin{tabular}{cccccc}
\hline \multirow{2}{*}{ Region } & \multicolumn{5}{c}{ Pool screen assay } \\
\cline { 2 - 6 } & Number examined & Pool size & Number of pools & Positive pools & Prevalence* \\
\hline North & 480 & 10 & 48 & 14 & $2.2-3.4-21.1$ \\
South & 450 & 10 & 45 & 17 & $3.2-4.7-26.1$ \\
East & 180 & 10 & 18 & 7 & $2.2-4.9-20.7$ \\
West & 120 & 10 & 12 & 7 & $3.7-8.4-25.2$ \\
\hline
\end{tabular}

\footnotetext{
*The center number in bold type represents the estimated prevalence, and the flanking values represent the $95 \%$ confidence interval of the prevalence estimate.
} 
Table 3. Leishmania infantum quantification in high burden sand fly samples.

\begin{tabular}{|c|c|c|c|c|}
\hline Region & Season & Trap & Sample number & $\begin{array}{c}\text { Parasite load } \\
(\text { mean } \pm \text { s.e.m. })^{*}\end{array}$ \\
\hline \multirow[t]{2}{*}{ North } & Wet & Indoors & 30 & $901.7 \pm 68.8$ \\
\hline & Wet & Outdoors & 3 & $542.3 \pm 11.9$ \\
\hline \multirow[t]{8}{*}{ South } & Wet & Indoors & 76 & $118.9 \pm 1.4$ \\
\hline & & & 68 & $314,681.8 \pm 23,645$ \\
\hline & & & 64 & $2,475,153.4 \pm 37,573$ \\
\hline & & Outdoors & 91 & $1,353,696.3 \pm 19,129$ \\
\hline & Dry & Indoors & 100 & $520.3 \pm 28.4$ \\
\hline & & & 101 & $3,565.9 \pm 139.4$ \\
\hline & & Outdoors & 105 & $261.0 \pm 8.8$ \\
\hline & & & 103 & $82,056.2 \pm 4,471$ \\
\hline \multirow[t]{3}{*}{ East } & Wet & Indoors & 109 & $7,337.7 \pm 452.0$ \\
\hline & & & 107 & $69,479.7 \pm 590.8$ \\
\hline & & Outdoors & 112 & $387,556.1 \pm 13,038$ \\
\hline West & Wet & Indoors & 125 & $2,820,246.0 \pm 106,072$ \\
\hline
\end{tabular}

*Mean of triplicate qPCR reactions.

Table 4. Leishmania infantum quantification in low burden sand fly samples.

\begin{tabular}{lccc}
\hline \multicolumn{1}{c}{ Region } & \multicolumn{2}{c}{ Number of samples } & Parasite load \\
\cline { 2 - 3 } & Analized & Positive (\%) & (mean \pm s.e.m)* \\
\hline North & 48 & $12(25.0)$ & $2.45 \pm 0.96$ \\
South & 45 & $9(20.0)$ & $10.57 \pm 5.98$ \\
East & 18 & $4(22.2)$ & $7.10 \pm 4.88$ \\
West & 12 & $6(50.0)$ & $4.77 \pm 1.36$ \\
Total & 123 & $31(25.2)$ & $5.86 \pm 1.91$ \\
\hline
\end{tabular}

${ }^{*}$ Mean of positive samples with low burden analized by qPCR.

No statistical differences were found $(\mathrm{P}>0.05)$ when analyzing the presence of L.infantum in sand-fly by trap location (indoors or outdoors) and by region.. Over the rainy and dry seasons there was no statistical difference in relation to sand-fly infection in the north, south and east regions. Only the west region showed statistical difference with a higher number of positive pools during the rainy season $(\mathrm{P}<0.05)$.

\section{Discussion}

The present work reports the use of real-time PCR assays for the detection and quantification of $L$. infantum in sandflies. The identification of Leishmania species circulating in a particular transmission focus is extremely important, especially when the goal is to study the epidemiology of the disease. It is known that the etiologic agent responsible for VL in the New World is L. infantum, but different regions of Brazil are endemic for both tegumentary leishmaniasis (TL) and VL (SCHALLING; OSKAM, 2002). For species identification, primers targeting the genomic DNA of L. infantum and L. braziliensis were used. For L. infantum, we used primers targeting MTHD. This enzyme is responsible for the synthesis of the thymidylate molecule, which is required for the parasite's metabolic function o (NARE et al., 1996). For L. braziliensis, we used primers targeting RNase III, which is involved in the degradation of double-stranded RNA and messenger RNA and in the processing of some ribosomal RNAs (SIMPSON et al., 2004).

The quantification of the parasite load in positive samples was performed using primers targeting the kDNA of Leishmania spp. The estimation of the parasite load in the vector is more sensitive and reliable when using primers targeting $\mathrm{kDNA}$, most likely due to the large number of copies of this DNA in the parasite minicircles (approximately 10,000 copies) (MARY et al., 2004; PRINA et al., 2007; BEZERRA-VASCONCELOS et al., 2011). Nicolas et al. (2002) reported a sensitivity of $100 \mathrm{fg}$ DNA/reaction for the qPCR assay used to monitor Leishmania spp infections in mice. Bezerra-Vasconcelos et al. (2011) obtained a sensitivity of $0.23 \mathrm{fg}$ DNA, equivalent to 0.004 parasites/reaction.

According to Anderson and May (1978), the distribution of the parasite load in the host is of the overdispersed type, with many hosts harboring few parasites and few hosts harboring many parasites. The number of parasites per phlebotomine is of great importance for the transmission of VL and the establishment of infection. However, the parasite burden measured in the pools should be interpreted carefully because the parasite burden may be different in each infected female, and the level of individual infection can affect the total parasite burden in the pool. For example, a high parasitic load in a particular sample could be due to the presence of one or more infected specimens (BEZERRAVASCONCELOS et al., 2011). Secundino et al. (2012) established a model of transmission through the L. longipalpis's bite and concluded that the infective dose of $L$. infantum for a single bite may vary from 10 to 10,000 parasites per sand-fly, with approximately $75 \%$ of the sandflies transmitting fewer than 300 parasites. The results of this study show that for most samples, the number of parasites was less than 300 .

The study of leishmaniasis epidemiology depends on the correct identification of vector species that occur in endemic areas to allow the estimation of the number of infections due to different species of Leishmania. Studies have been conducted in endemic areas using the dissection of sandflies and the identification of the 
parasite or molecular techniques to detect Leishmania spp DNA (PEREZ et al., 1994). Molecular techniques, such as qPCR, are a sensitive diagnostic method because they allow the DNA detection corresponding to 0.004 parasites per reaction (BEZERRAVASCONCELOS et al., 2011). However, only dissection can confirm that parasites undergo maturation towards infective forms and are not eliminated after defecation (SVARÓVSKÁ et al., 2010).

In the present study, the rate of natural infection was similar to that determined by Goméz-Saladín et al. (2005), used qPCR and reported an infection rate of $2.9 \%$ in sandflies collected in Italy. In Brazil, the estimated infection rate was $0.2 \%$ in Bahia (SHERLOCK, 1996), 2.6\% in Mato Grosso do Sul (NASCIMENTO et al., 2007) and 3.9\% in Minas Gerais (MICHALSKY et al., 2011).

The rainy season yielded the highest number of positive samples; however, the difference between the rainy and dry season was not significant except in the west region. This trend for the greater prevalence of $L$. longipalpis in the rainy season was previously observed in the 1960s in semi-arid areas in northeastern Brazil. In endemic areas for VL, such as the states of Ceará and Bahia, the $L$. longipalpis populations increased in the rainy season (SHERLOCK; GUITTON, 1969). However, in other areas, this pattern can change. In eastern Costa Rica, an area with warm weather and low rainfall that is endemic for VL, similar to the northeast of Brazil, the highest abundance of $L$. longipalpis occurs in the dry season (ZELEDÓN et al., 1984). According to Oliveira et al. (2013), L. longipalpis can be found during each month of the year, although the presence of a large number of sandflies coincides with the periods before and after the rainy season. However, in other states of Brazil, such as Mato Grosso do Sul, Maranhão and Minas Gerais, there are more sandflies during the rainy season (GALATI et al., 1997; REBÊLO, 2001; RESENDE et al., 2006). Probably, the high prevalence of infected sandflies in the rainy season is correlated to social-environmental factors in the west region of the city of Fortaleza. This region is cut by the Maranguapinho river, with an extensive wooden part. Furthermore, it is a poor area of the city with a high number of human and canine cases of VL, factors that may contribute to the emergence of sandflies (FERNANDEZ et al., 2010).

VL is an endemic in the state of Ceará since 1930, where cases were reported for the first time. In 2009, 787 cases were reported, with 432 confirmed cases and 16 deaths. The largest number of reported cases was in Fortaleza (194), considered an area of intense transmission, according to the Brazilian Ministry of Health (CEARÁ, 2012).

The difference in the number of positive samples between those collected indoors and those collected outdoors was not significant. This result differed from the results found by Silva et al. (2008), in the state of Mato Grosso do Sul, where a greater number of positive samples were found indoors.

The pool screen assay is capable of detecting a single infected individual in a pooled sample (KATHOLI et al., 1995). Furthermore, the use of the pool screen assay makes it possible to determine the prevalence in a given area with a limited investment of human and material resources. Thus, this technique may be a valuable tool for the surveillance activities to be conducted in the area. Furthermore, the pool screen assay is an efficient means to screen large numbers of infected flies (YAMEOGO et al., 1999).
Based on these results, we can infer that the use of qPCR for the detection and quantification of L. infantum in sand-fly pools succeeded in detecting the region and the season with the highest number of infected sandflies. Additionally, this detection may be useful in targeting risk areas and implement control strategies, which are: diagnosis and treatment of human cases, identification and elimination of reservoirs, vector control, and health education.

\section{Acknowledgments}

We thank Dr. Maria Jania Teixeira from the University Federal of Ceará whose technical support was essential. The authors are grateful to the CAPES and CNPq for scholarships.

\section{References}

Anderson RM, May RM. Regulation and stability of host-parasite population interactions. J Anim Ecol 1978; 47(1): 219-247. http:// dx.doi.org/10.2307/3933

Bezerra-Vasconcelos DR, Melo LM, Albuquerque ES, Luciano MCS, Bevilaqua CML. Real-time PCR to assess the Leishmania load in Lutzomyia longipalpis sand flies: Screening of target genes and assessment of quantitative methods. Exp Parasitol 2011; 129(3): 234-239. PMid:21864530. http://dx.doi.org/10.1016/j.exppara.2011.08.010

Ceará. Secretaria de Saúde do Estado. Núcleo de Epidemiologia (NUVEP/SESA). Informe Epidemiológico - Leishmaniose Visceral [online]. 2012. Avaliable from: http://www.google.com.br/url?sa=t\&r $\mathrm{ct}=\mathrm{j} \& \mathrm{q}=\&$ esr $\mathrm{c}=\mathrm{s} \&$ source $=$ web $\& \mathrm{~cd}=1 \& \mathrm{ved}=0 \mathrm{CC} 8 \mathrm{QFjAA} \& \mathrm{url}=\mathrm{http} \%$ 3A\%2F\%2Fwww.saude.ce.gov.br\%2Findex.php\%2Fboletins\%3Fdow nload\%3D56\%253A-leishmaniose-visceral-fevereiro-de 2010\&ei=WL VUuGLJ4ivkae71ICoDA\&usg=AFQjCNEqIbJ3i3vLqUVd2vwGhLf qFhgog\&bvm=bv.59378465,d.eW0.

Cuvillier A, Miranda JC, Ambit A, Barral A, Merlin G. Abortive infection of Lutzomyia longipalpis insect vectors by aflagellate LdARL3A-Q70L overexpressing Leishmania amazonensis parasites. Cell Microbiol 2003; 5(10): 717-728. PMid:12969377. http://dx.doi. org/10.1046/j.1462-5822.2003.00316.x

Desjeux P. Leishmaniasis: current situation and new perspectives. Comp Immunol Microbiol Infect Dis 2004; 27(5): 305-318. PMid:15225981. http://dx.doi.org/10.1016/j.cimid.2004.03.004

Fernandez MS, Salomón OD, Cavia R, Perez AA, Acardi SA, Guccione JD. Lutzomyia longipalpis spatial distribution and association with environmental variables in an urban focus of visceral leishmaniasis, Misiones, Argentina. Acta Trop 2010; 114(2): 81-87. PMid:20096256. http://dx.doi.org/10.1016/j.actatropica.2010.01.008

Galati EAB, Nunes VLB, Rego FA Jr, Oshiro ET, Chang MR. Estudo de flebotomíneos (Diptera, Psychodidae) em foco de leishmaniose visceral no Estado de Mato Grosso do Sul, Brasil. Rev Saúde Pública 1997; 31(4):378-390. PMid:9595767. http://dx.doi. org/10.1590/S0034-89101997000400007

Goméz-Saladín E, Doud CW, Maroli M. Short report: Surveillance of Leishmania sp. Among sand flies in Sicily (Italy) using a fluorogenic realtime polymerase chain reaction. Am J Trop Med Hyg 2005; 72(2): 138 141. PMid: 15741548 
Gontijo CMF, Melo MN. Leishmaniose visceral no Brasil: quadro atual, desafios e perspectivas. Rev Bras Epidemiol 2004; 7(3): 338-349. http:// dx.doi.org/10.1590/S1415-790X2004000300011

Instituto Brasileiro de Geografia e Estatística - IBGE [online]. 2011 [cited 2011 Oct 10]. Available from: http://www.ibge.gov.br/cidadesat/ painel/painel.php?codmun=230440.

Katholi C, Toé L, Merriweather A, Unnasch TR. Determining the prevalence of Onchocerca volvulus infection in vector populations by Polymerase Chain Reaction screening of pools of black flies. $J$ Infect Dis 1995; 172(5): 1414-1417. PMid:7594692. http://dx.doi. org/10.1093/infdis/172.5.1414

Killick-Kendrick R. The biology and control of phlebotomine sand flies. Clin Dermatol 1999; 17(3): 279-289. http://dx.doi.org/10.1016/ S0738-081X(99)00046-2

Kimblin N, Peters N, Debrabant A, Secundino N, Egen J, Lawyer P, et al. Quantification of the infectious dose of Leishmania major transmitted to the skin by single sand flies. Proc Natl Acad Sci USA 2008; 105(29): 1012510130. PMid:18626016 PMCid:PMC2481378. http://dx.doi. org/10.1073/pnas.0802331105

Mary C, Faraut F, Lascombe F, Dumon H. Quantification of Leishmania infantum DNA by a real-time PCR assay with high sensitivity. J Clin Microbiol 2004; 42(11): 5249-5255. PMid:15528722 PMCid:PMC525214. http://dx.doi.org/10.1128/JCM.42.11.52495255.2004

Michalsky EM, Guedes KS, Silva FOL, França-Silva JC, Dias CLF, Barata RA, et al. Infecção natural de Lutzomyia (Lutzomyia) longipalpis (Diptera: Psychodidae) por Leishmania infantum chagasi em flebotomíneos capturados no município de Janaúba, Estado de Minas Gerais, Brasil. Rev Soc Bras Med Trop 2011; 44(1): 58-62. PMid:21340410. http:// dx.doi.org/10.1590/S0037-86822011000100014

Montoya-Lerma J, Cadena H, Oviedo M, Ready PD, Barazarte R, Travi BL, et al. Comparative vectorial efficiency of Lutzomyia evansi and $L u$. longipalpis for transmitting Leishmania chagasi. Acta Trop 2003; 85(1):1929. http://dx.doi.org/10.1016/S0001-706X(02)00189-4

Nare B, Hardy LW, Beverley SM. The roles of pteridine reductase 1 and dihydrofolate reductase-thymidylate synthase in pteridine metabolism in the protozoan parasite Leishmania major. J Biol Chem 1996; 272(21): 13883-13891. http://dx.doi.org/10.1074/ jbc.272.21.13883

Nascimento JC, Paiva BR, Malafronte RS, Fernandes WD, Galati EAB. Natural infection of phlebotomines (Diptera: Psychodidae) in a visceral-leishmaniasis focus in Mato Grosso do Sul, Brazil. Rev Inst Med Trop Sao Paulo 2007; 49(2): 119-122. PMid:17505673. http://dx.doi. org/10.1590/S0036-46652007000200011

Nicolas L, Prina E, Lang T, Milon G. Real-time PCR for detection and quantitation of Leishmania in mouse tissues. J Clin Microbiol 2002; 40: 1666-1669. PMid:11980939 PMCid:PMC130941. http://dx.doi.org/10.1128/JCM.40.5.1666-1669.2002

Oliveira CI, Teixeira MJ, Teixeira CR, Jesus JR, Rosato AB, Silva JS, et al. Leishmania braziliensis isolates differing at the genome level display distinctive features in BALB/c mice. Microbes Infect 2004; 6(11): $977-$ 984. PMid:15345228. http://dx.doi.org/10.1016/j.micinf.2004.05.009

Oliveira EF, Fernandes CES, Silva EA, Brazil RP, Oliveira AG. Climatic factors and population density of Lutzomyia longipalpis(Lutz \& Neiva, 1912) in na urban endemic área of visceral leishmaniasis in midwest Brazil. J Vector Ecol 2013; 38(2): 224-228. http://dx.doi. org/10.1111/j.1948-7134.2013.12034.x
Paiva BR, Secundino NFC, Nascimento JC, Pimenta PF, Galati EA, Andrade HF Jr, et al. Detection and identification of Leishmania species in field-captured phlebotomine sandflies based on mini-exon gene PCR. Acta Trop 2006; 99(2-3): 252-259. PMid:17055444. http://dx.doi. org/10.1016/j.actatropica.2006.08.009

Paiva BR, Secundino NFC, Pimenta PFP, Galati EAB, Andrade HF Jr, Malafronte RS. Padronizaçáo de condiçôes para detecção de DNA de Leishmania spp. em flebotomíneos (Diptera, Psychodidae) pela reação em cadeia da polimerase. Cad Saúde Pública 2007; 23(1): 8794. PMid:17187107. http://dx.doi.org/10.1590/S0102311X2007000100010

Peacock CS, Seeger K, Harris D, Murphy L, Ruiz JC, Quail MA, et al. Comparative genomic analysis of three Leishmania species that cause diverse human disease. Nat Genet 2007; 39(7): 839-847. PMid:17572675 PMCid:PMC2592530. http://dx.doi.org/10.1038/ng2053

Perez JE, Ogusuku E, Inga R, Lopez M, Monje J, Paz L, et al. Natural Leishmania infection of Lutzomyia spp. in Peru. Trans $R$ Soc Trop Med Hyg 1994; 88(2): 161-164. http://dx.doi.org/10.1016/00359203(94)90276-3

Perez JE, Veland N, Espinosa D, Torres K, Ogusuku E, LlanosCuentas A, et al. Isolation and molecular identification of Leishmania (Viannia) peruviana from naturally infected Lutzomyia peruensis (Diptera: Psychodidae) in the Peruvian Andes. Mem Inst Oswaldo Cruz 2007; 102(5): 655-658. PMid:17710315. http://dx.doi. org/10.1590/S0074-02762007005000077

Prina E, Roux E, Mattei D, Milon G. Leishmania DNA is rapidly degraded following parasite death: an analysis by microscopy and realtime PCR. Microbes Infect 2007; 9(11): 1307-1315. PMid:17890124. http://dx.doi.org/10.1016/j.micinf.2007.06.005

Quinnell RJ, Courtenay O. Transmission, reservoir hosts and control of zoonotic visceral leishmaniasis. Parasitology 2009; 136(14): 1915-1934. PMid:19835643. http://dx.doi.org/10.1017/S0031182009991156

Ranasinghe S, Rogers ME, Hamilton JGC, Bates PA, Maingon RDC. A real-time PCR assay to estimate Leishmania chagasi load in its natural sandfly vector Lutzomyia longipalpis. Trans $R$ Soc Trop Med Hyg 2008; 102(9): 875-882. PMid:18501935 PMCid:PMC2678673. http://dx.doi.org/10.1016/j.trstmh.2008.04.003

Rebêlo JM. Hourly frequency and seasonality of Lutzomyia longipalpis (Diptera: Psychodidae: Phlebotominae) on São Luís Island, Maranhão, Brazil. Cad Saúde Pública 2001; 17(1): 221-227. PMid:11241945. http:// dx.doi.org/10.1590/S0102-311X2001000100023

Resende MC, Camargo MCV, Vieira JRM, Nobi RCA, Porto NMN, Oliveira CD, et al. Seasonal variation of Lutzomyia longipalpis in Belo Horizonte, state of Minas Gerais. Rev Soc Bras Med Trop 2006; 39(1): 51-55. PMid:16501767. http://dx.doi.org/10.1590/ S0037-86822006000100010

Sadlova J, Yeo M, Seblova V, Lewis MD, Mauricio I, Volf P, et al. Visualisation of Leishmania donovani fluorescent hybrids during early stage development in the sand fly vector. PloS One 2011; 6(5): e19851. PMid:21637755 PMCid:PMC3103508. http://dx.doi.org/10.1371/ journal.pone.0019851

Schalling HDFH, Oskam L. Molecular biological applications in the diagnosis and control of leishmaniasis and parasite identification. Trop Med Int Health 2002; 7(8): 641-651. http://dx.doi.org/10.1046/j.13653156.2002.00911.x

Secundino NFC, Freitas VC, Monteiro CC, Pires ACAM, David BA, Pimenta PFP. The transmission of Leishmania infantum chagasi by the 
bite of the Lutzomyia longipalpis to two different vertebrates. Parasit Vectors 2012; 5: 20. PMid:22260275 PMCid:PMC3293046. http:// dx.doi.org/10.1186/1756-3305-5-20

Sherlock IA. Ecological interactions of visceral leishmaniasis in the State of Bahia, Brazil. Mem Inst Oswaldo Cruz 1996; 91(6): 671-683. PMid:9283643. http://dx.doi.org/10.1590/S0074-02761996000600003

Sherlock IA, Guitton N. Observaçóes sobre calazar em Jacobina, Bahia. IV. Variação horária e estacional de Phlebotomus longipalpis. Rev Bras Malar Doenças Trop 1969; 21: 715-727. PMid:5397212.

Silva EA, Andreotti R, Dias ES, Barros JC, Brazuna JCM. Detection of Leishmania DNA in phlebotomines captured in Campo Grande, Mato Grosso do Sul, Brazil. Exp Parasitol 2008; 119(3): 343-348. PMid:18456262. http://dx.doi.org/10.1016/j.exppara.2008.03.011

Simpson L, Aphasizhev R, Gao G, Kang X. Mitochondrial proteins and complexes in Leishmania and Trypanosoma involved in U-insertion/ deletion RNA editing. RNA 2004; 10(2): 159-170. PMid:14730014 PMCid:PMC1370527. http://dx.doi.org/10.1261/rna.5170704

Soares MRA, Carvalho CC, Silva LA, Lima MSCS, Barral AMP, Rebêlo JMM, et al. Análise molecular da infecção natural de Lutzomyia longipalpis em área endêmica de leishmaniose visceral no Brasil. Cad Saúde Pública 2010; 26(12): 2409-2413. PMid:21243235. http://dx.doi. org/10.1590/S0102-311X2010001200019
Sudia WD, Chamberlain RW. Battery-operated light trap, an improved model. Mosq News 1962; 22: 126-129.

Svaróvská A, Ant TH, Seblová V, Jecná L, Beverley SM, Volf P. Leishmania major glycosylation mutants require phosphoglycans (Ipg2-) but not lipophosphoglycan (Ipg1) for survival in permissive sand fly vectors. PloS Negl Trop Dis; 2010; 4(1): e580. PMid:20084096 PMCid:PMC2797086. http://dx.doi.org/10.1371/journal.pntd.0000580

Yameogo L, Toe L, Hougard JM, Boatin BA, Unnasch TR. Pool screen polymerase chain reaction for estimating the prevalence of Onchocerca volvulus infection in Simulium damnosum sensu lato: results of a field trial in an area subject to successful vector control. Am J Trop Med Hyg 1999; 60(1): 124-128. PMid:9988335.

Young DG, Duncan MA. Guide to the Identification and Geographic Distribution of Lutzomyia Sand Flies in Mexico, the West Indies, Central and South America (Diptera: Psychodidae). Gainesville: Associate Publishers; 1994. p. 104-140. In: Memorial American Institute Entomology.

Zeledón R, Murillo J, Gutierrez H. Observaciones sobre la ecología de Lutzomyia longipalpis (Lutz \& Neiva, 1912) y posibilidades de existencia de leishmaniasis visceral en Costa Rica. Mem Inst Oswaldo Cruz 1984; 79(4): 455-459. http://dx.doi.org/10.1590/S007402761984000400010 